\title{
Determinants of successful delivery by non-state actors: an exploratory study
}

\author{
Puig, Daniel; Bakhtiari, Fatemeh
}

Published in:

International Environmental Agreements: Politics, Law and Economics

Link to article, DOI:

10.1007/s10784-020-09482-8

Publication date:

2021

Document Version

Peer reviewed version

Link back to DTU Orbit

Citation (APA):

Puig, D., \& Bakhtiari, F. (2021). Determinants of successful delivery by non-state actors: an exploratory study. International Environmental Agreements: Politics, Law and Economics, 21, 93-111.

https://doi.org/10.1007/s10784-020-09482-8

\section{General rights}

Copyright and moral rights for the publications made accessible in the public portal are retained by the authors and/or other copyright owners and it is a condition of accessing publications that users recognise and abide by the legal requirements associated with these rights.

- Users may download and print one copy of any publication from the public portal for the purpose of private study or research

- You may not further distribute the material or use it for any profit-making activity or commercial gain

- You may freely distribute the URL identifying the publication in the public portal

If you believe that this document breaches copyright please contact us providing details, and we will remove access to the work immediately and investigate your claim. 
Title

Determinants of successful delivery by non-state actors: an exploratory study

\section{Authors}

Daniel Puig (corresp. author) | ORCID: 0000-0001-9165-6838 | dapu@dtu.dk | Tel.: +45 45335253

Technical University of Denmark | Marmorvej, 51 | Copenhagen $\varnothing \mid$ Denmark

Fatemeh Bakhtiari | ORCID: 0000-0002-9123-4173 | fatebak@dtu.dk | Tel.: +45 45335292

Technical University of Denmark | Marmorvej, 51 | Copenhagen $\varnothing \mid$ Denmark

\section{Journal}

International Environmental Agreements: Politics, Law and Economics

\section{Abstract}

Parties to the United Nations Framework Convention on Climate Change are giving an increasingly prominent role to non-state actor action. Reflecting this development, significant research efforts have gone into studying non-state actor actions. However, the literature shows a paucity of studies of the determinants of delivery by non-state actors. The article asks the following question: what is the full range of determinants of delivery by non-state actor focused on adaptation to climate change and disaster risk reduction? Drawing on data collected through interviews with, and a survey of, core partners in a selection of non-state actor actions, the article puts forward a taxonomy that can help gauge the likelihood that a non-state actor action may be able to deliver on its intended objectives. The findings presented in the article reveal that several of the determinants of delivery by non-state actors are outside of the sphere of influence of the core partners in these actions. The article makes the case for using this kind of taxonomies to conducting ex-ante assessments of nonstate actor actions, with a view to reflecting the results of the assessments in the design of the action, thus increasing the quality of non-state actor action. 


\section{Manuscript}

\section{Introduction}

Transnational governance has been defined as the set of «processes in which nonstate actors adopt rules that seek to move behavior toward a shared, public goal in at least two states» (Roger and Dauvergne, 2016). 'By nonstate actors, Roger and Dauvergne refer to non-governmental entities, thus entirely excluding governmental entities, whether they are national, sub-national or supranational entities. In this article, non-state actor action refers to any combination of entities that are not exclusively governmental entities (Supplementary Information 1).

The surge in transnational governance schemes «can be traced back to the incipient globalisation that followed the liberalisation of trade markets in the mid-1970s» (Bakhtiari, 2017). Founded in 1990, the Climate Alliance, a coalition of sub-national governments, is possibly the first transnational governance scheme focused on climate-change management (ibid).

In 2015, through its Paris Agreement, the United Nations Framework Convention on Climate Change (UNFCCC) declared that «non-party stakeholders» (that is, parties other than the signatory parties to the UNFCCC, thus including non-state actors) may contribute to achieving the UNFCCC's mitigation and adaptation goals (UNFCCC, 2015). ii Most recently, the decisions adopted the December 2019 conference of the parties to the UNFCCC re-stated the importance that party stakeholders give to non-state actors (UNFCCC, 2019). There are no indications to suggest that the growing institutionalisation of the role of non-state actors in international climate-change negotiations will reverse in the near future (Bulkeley et al., 2018).

Against this background, the proliferation of transnational climate change-governance schemes should come as no surprise. Yet, in spite of the political support that these schemes enjoy, there is no commonly agreed definition of what constitutes a non-state actor action (Supplementary Information 1). This hampers efforts to inventory and study non-state actor actions (Fenhann et al., 2018). Notwithstanding, it is clear that most climate change-related non-state actor actions focus on climate change mitigation, with just a few covering (exclusively) adaptation to climate change and disaster-risk reduction (CIP, 2019). ${ }^{\text {iii }}$

Irrespective of whether they focus on climate-change mitigation, adaptation, or disaster-risk reduction, studies of non-state actor action can be characterised according to the types of impact direct or indirect - that they explore. We define direct and indirect impacts as follows:

- Direct impact refers to the delivery of tangible climate change-management outcomes within a given period of time. A tangible outcome is understood as changes in technologies or practices that, in themselves, result in reductions in greenhouse-gas emissions, or increases in resilience to the impacts of climate change. These outcomes are the direct consequence of the operations of the non-state actor action, and are additional to any other related efforts to deliver climate change-management outcomes (notably, efforts led by state actors). Stated differently, within the selected period of time, the climate change-management outcomes attributable to the nonstate actor action would not have been delivered, neither partially nor totally, had the nonstate actor action not been in operation.

- Indirect impact refers to the changes in practices, improvements in technical capacities and increases in financial resources or information flows that, over a given period of time, facilitate 
the delivery of direct climate change-management outcomes by other actors, notably state actors. Stated differently, within the selected period of time, the work of the non-state actor action increases the pace with which other (state or non-state) actors can deliver climate change-management outcomes that they would have attempted to deliver as a part of their regular operations.

Most research on non-state actors focuses on direct impacts. Estimates of the level of greenhousegas emission reductions that these actions could achieve make up a distinct research stream (Hsu et al., 2018). Next to this type of work, governance constitutes a second area of research, contributing both theoretical (Andonova et al., 2009) and empirical (Andonova et al., 2017) studies that target all governance levels, from local, to national, to global. ${ }^{\text {iv }}$ Additional research on direct impacts by non-state actor actions includes studies focused on international climate-change negotiations (Hermwille, 2018), specific actors such as cities (Bulkeley and Schroeder, 2012), or the geographic distribution of the actions (Chan et al., 2018), among other topics.

The study of indirect impacts has attracted less attention, in spite of calls to consider such impacts (van der Ven et al., 2017). In general, indirect impacts are characterised as being «catalytic and political - contributing to normative change, building the capacities of political actors and altering coalition-building and conflict dynamics [...] in addition to, or even instead of, quantifiable emissions reductions» (Bulkeley et al., 2018). ${ }^{\vee}$ This characterisation could be expanded beyond "quantifiable emission reductions", to include increases in resilience to the impacts of climate change, or reductions in disaster risk.

In reality, the divide between direct and indirect impacts is somewhat artificial, as few, if any, nonstate actor actions achieve one type of impact only (CIP, 2019). For example, the Global Resilience Partnership, a non-state actor action whose primary goal is to increase the resilience of poor communities to various impacts of climate change, has also contributed to increasing the ability of bilateral donors to coordinate their climate change-adaptation portfolios (an indirect impact) (GRP, 2019). Similarly, CDP's initial work to foster private sector disclosure of climate change-related data (an indirect impact) has led to actual reductions in greenhouse-gas emissions by many CDP members (CDP, 2019).

Few authors have put forward criteria that can be used to assess the extent to which a non-state actor action is likely to deliver on its objectives, irrespective of the main type of impact - direct or indirect - that is concerned. Widerberg and Pattberg (2015) developed three sets of criteria exploring, respectively, the effectiveness, legitimacy and "institutional fitness" of non-state actor actions. For example, one of the two effectiveness criteria focuses on the extent to which a given non-state actor action has access to the required type and amount of resources. Michaelowa and Michaelowa (2017) screen non-state actor actions against three "design criteria": the extent to which (i) explicit targets have been set; (ii) incentives are available; and (iii) monitoring, reporting and verification procedures have been adopted. Finally, Chan and Amling (2019) rely on twelve predefined "functional categories" to assess whether the outputs of a given non-state actor action are consistent with the function(s) that the action in question seeks to deliver. Examples of functions include knowledge dissemination and policy planning, among others.

It is unclear whether the criteria above represent the full range of determinants of successful delivery. Therefore, we explore the following research question: what is the full range of determinants of delivery by non-state actor focused on adaptation to climate change and disaster risk reduction? To answer this question, we study a selection of six non-state actor actions, to gain insights on the determinants of successful delivery by these actions. We choose non-state actor 
actions whose direct impacts concern (exclusively) adaptation to climate change or disaster-risk reduction. We make this choice because, compared to research on non-state actor actions focused on climate-change mitigation, adaptation and disaster-risk reduction are under-studied areas. ${ }^{\text {vi }}$ With regard to indirect impacts, we examine two widely cited types of impacts: mobilising private-sector funding, and catalysing related, complementary action by state actors.

We rely on semi-structured interviews, complemented with a survey. We use the interviews to learn the interviewees' points of view with regard to the determinants of successful delivery by non-state actor actions. The survey, which focuses on factual data about the various non-state actor actions studied, helps us put into perspective the feedback provided by the interviewees. We use these data to inductively develop a taxonomy for assessing the likelihood that delivery by non-state actor actions may be successful. We compare our taxonomy with the criteria put forward in the literature, to check if those criteria are consistent with our taxonomy. Our findings allow us to make a number of recommendations of relevance to future non-state actor actions focused on adaptation or disaster-risk reduction.

The remainder of the article is structured around four additional sections. Section 2 summarises the type of data that we have collected, and the process that we followed to collect it. Section 3 describes our findings, the implications of which are discussed in Section 4. Concluding considerations are presented in Section 5.

\section{Methods}

This section is structured around two sub-sections. First, the process followed to select the non-state actor actions is outlined. Following this, details of the data collection process are provided.

\subsection{Selection of non-state actor actions}

The literature includes several databases of non-state actor actions, which differ substantially in scope (Höhne and Drost, 2015). At least two reasons account for this. First, there is no single definition of non-state actor action (Supplementary Information 1). Second, the purpose of a database determines the selection of non-state actor actions included in it (Widerberg and Stripple, 2016). As a result, we had to rely on multiple sources to identify the non-state actor actions that were relevant to our research. As stated above, we target actions that focus exclusively on adaptation or disaster-risk reduction. ${ }^{\text {vi }}$

An initial search returned nine relevant non-state actor actions. viii Semi-structured interviews with the managers of each of these nine actions were used to get three types of feedback. First, the interviewees helped us judge the extent to which the actions were consistent with our definition (Supplementary Information 1). Second, feedback from the interviewees was critical to determine whether the actions had been active for long enough to be able to respond to our questions, as this information is seldom disclosed in the documentation that non-state actor actions make publicly available. ${ }^{\text {ix }}$ Third, the interviewees helped us identify additional non-state actor actions that could be of potential interest to us and had not been captured through our search.

This screening process allowed us to discard four actions: three of them were at the early stages of their work, and one of them did not fit our definition. In addition, the screening process allowed us to identify one additional action that did meet our eligibility criteria. In sum, at the end of the screening process we had identified six non-state actor actions that were eligible for the analysis. 
Three of these actions focus on adaptation to climate change and the remaining three focus on disaster-risk reduction (Table 1).

Table 1: Non-state actor actions surveyed

\begin{tabular}{|l|l|}
\hline Non-state actor action & Focus area \\
\hline Business Alliance for Water and Climate & Climate change adaptation \\
\hline Crisis Anticipation Window & Disaster-risk reduction \\
\hline Forecast-based Financing & Disaster-risk reduction \\
\hline RegionsAdapt & Climate change adaptation \\
\hline Rural Resilience Initiative & Disaster-risk reduction \\
\hline Urban Community Resilience Assessment & Climate change adaptation \\
\hline
\end{tabular}

\subsection{Data collection}

Reporting by non-state actor actions remains limited at best (Fenhann et al., 2018). As a result, the little data available is neither comprehensive nor comparable across non-state actor actions. For this reason, we conducted a survey among the six non-state actor actions identified, and interviewed the core partners in each action. ${ }^{x}$

The survey consisted of two questionnaires, to which we referred as "Form A" and "Form B" (Supplementary Information 2). For each non-state actor action, we collected one response to Form A, jointly prepared by the core partners in the action, because the questions in this form capture the main features of the non-state actor action itself. Form B was filled out individually by each of the core partners in a non-state actor action, because the questions in this form capture issues that are specific to an individual organisation. In short, for each non-state actor action surveyed, we collected one response to Form A, and as many responses to Form B as core partners in the action. ${ }^{\mathrm{x}}$

In both forms, some of the questions allowed for responses that could be defined in advance. Examples of this type of questions include the countries in which a non-state actor action is active, or the descriptor (governmental agency, private sector, non-governmental advocacy group, or academia) that best characterises a partner in the non-state actor action. These questions were phrased as multiple-choice questions. However, a second set of questions were not amenable to a multiple-choice phrasing. The incentive that an organisation may have in joining a non-state actor action, or the delivery mechanisms of the action are examples of this type of questions.

Nonetheless, to introduce a minimum level of convergence in the responses, without leading respondents and thus potentially losing granularity, the questionnaire included certain examples. These examples reflected the preliminary feedback provided by the respondents themselves (see footnote 10). Respondents were encouraged to provide a succinct response, without necessarily limiting themselves to the examples included in the questionnaire.

For each non-state actor action, we interviewed the core partners in the action. We asked for their views on the determinants of successful delivery, understood as the enablers of, and barriers to, delivery of the action's intended objectives.

We encouraged our interviewees to consider as broad a range of issues as possible, including issues that are out of the control of the partners in the action. Our goal with this suggestion was twofold. 
First, to avoid unduly narrow responses that only consider issues that are within the boundaries of the non-state actor action. Second, to introduce as light and non-constraining a framework as possible.

\section{Results}

This section is structured around three elements. First, we present an overview of the results of our survey of six non-state actor actions. Second, we report on the interviews that we conducted. Third, we introduce a taxonomy for assessing the likelihood that delivery by non-state actor actions may be successful. The taxonomy is developed inductively, drawing on the information collected through the survey and the interviews.

\subsection{Survey results}

Supplementary Information 3 provides a narrative synthesis of the results of the survey, including the stated objectives (Table SI3.1) and purported net benefits (Table SI3.2) of each of the individual non-state actor actions surveyed. Table 2 gives a tabular overview of the survey results. Together, these elements provide context to the feedback collected through our interviews (Section 3.2).

Three of the non-state actor actions surveyed focus on planning for climate change adaptation, whereas the remaining three focus on mobilising and channelling funding for disaster-risk reduction. In general, we find that, compared to the former, the latter (i) present less or no overlap with work by state actors, (ii) use innovative delivery mechanisms, and (iii) represent a major part of the portfolio of activities for at least one of the core partners in the action.

All six non-state actor actions are on course to deliver on their intended direct impacts. ${ }^{\text {xii xiii }}$ With regard to indirect impacts, we consider two widely cited types: mobilising private-sector funding, and catalysing related, complementary action by state actors. Only the three non-state actor actions focused on disaster-risk reduction have been successful at mobilising private-sector funding. Two of the actions focused on disaster-risk reduction have been successful at catalysing related, complementary action by state actors.

Four out of the six non-state actor actions surveyed report on their activities, mainly as a response to donor requirements. In other words, in spite of longstanding calls for heightened disclosure (Höhne and Drost, 2015), reports targeting stakeholders other than donors are rare. Of the remaining two non-state actor actions, one action reports annually to international climate-change negotiators, whereas the second action produces no reports. 
Table 2:

Overview of the responses to the survey

\begin{tabular}{|c|c|c|c|c|c|c|}
\hline & $\begin{array}{l}\text { Business Alliance } \\
\text { for Water and } \\
\text { Climate }\end{array}$ & $\begin{array}{c}\text { Crisis } \\
\text { Anticipation } \\
\text { Window }\end{array}$ & $\begin{array}{l}\text { Forecast-based } \\
\text { Financing }\end{array}$ & RegionsAdapt & $\begin{array}{l}\text { Rural Resilience } \\
\text { Initiative }\end{array}$ & $\begin{array}{c}\text { Urban } \\
\text { Community } \\
\text { Resilience } \\
\text { Assessment }\end{array}$ \\
\hline $\begin{array}{l}\text { Nature of the } \\
\text { objectives }\end{array}$ & Qualitative & Qualitative & Qualitative & Qualitative & $\begin{array}{l}\text { Qualitative } \\
\text { (although some } \\
\text { are quantitative) }\end{array}$ & Qualitative \\
\hline $\begin{array}{l}\text { Intended } \\
\text { benefits }\end{array}$ & Support planning & $\begin{array}{l}\text { Mobilise and } \\
\text { channel funding }\end{array}$ & $\begin{array}{l}\text { Mobilise and } \\
\text { channel funding }\end{array}$ & Support planning & $\begin{array}{l}\text { Mobilise and } \\
\text { channel funding }\end{array}$ & Support planning \\
\hline $\begin{array}{l}\text { Overlap with } \\
\text { state actor } \\
\text { action }\end{array}$ & Some & None & None & Some & None & Some \\
\hline $\begin{array}{l}\text { Catalyse } \\
\text { complementary } \\
\text { state actor } \\
\text { action }\end{array}$ & No & $\begin{array}{l}\text { No (but progress } \\
\text { made) }\end{array}$ & Yes & No & Yes & No \\
\hline $\begin{array}{l}\text { Mobilisation of } \\
\text { private sector } \\
\text { funding }\end{array}$ & Not attempted & Yes & Yes & No & Yes & No \\
\hline Reporting & $\begin{array}{l}\text { Annual reports } \\
\text { to the UNFCCC } \\
\text { COP }\end{array}$ & $\begin{array}{l}\text { To fulfil donor } \\
\text { requirements }\end{array}$ & $\begin{array}{l}\text { To fulfil donor } \\
\text { requirements }\end{array}$ & $\begin{array}{l}\text { None (although } \\
\text { members report } \\
\text { individually to } \\
\text { the secretariat } \\
\text { and to CDP) }\end{array}$ & $\begin{array}{l}\text { To fulfil donor } \\
\text { requirements }\end{array}$ & $\begin{array}{l}\text { To fulfil donor } \\
\text { requirements }\end{array}$ \\
\hline
\end{tabular}

Note: UNFCCC COP stands for conference of the parties to the United Nations Framework Convention on Climate Change 
Table 2:

Overview of the responses to the survey (continued)

\begin{tabular}{|c|c|c|c|c|c|c|}
\hline & $\begin{array}{c}\text { Business Alliance } \\
\text { for Water and } \\
\text { Climate }\end{array}$ & $\begin{array}{c}\text { Crisis } \\
\text { Anticipation } \\
\text { Window }\end{array}$ & $\begin{array}{l}\text { Forecast-based } \\
\text { Financing }\end{array}$ & RegionsAdapt & $\begin{array}{l}\text { Rural Resilience } \\
\text { Initiative }\end{array}$ & $\begin{array}{l}\text { Urban } \\
\text { Community } \\
\text { Resilience } \\
\text { Assessment }\end{array}$ \\
\hline $\begin{array}{l}\text { Governance } \\
\text { arrangements }\end{array}$ & Horizontal & Horizontal & $\begin{array}{l}\text { Hierarchical (for } \\
\text { the setting up of } \\
\text { the action) and } \\
\text { horizontal (for } \\
\text { running the } \\
\text { action) }\end{array}$ & Horizontal & Orchestrated & Horizontal \\
\hline $\begin{array}{l}\text { Innovative } \\
\text { delivery } \\
\text { mechanisms }\end{array}$ & $\begin{array}{l}\text { No (knowledge } \\
\text { dissemination) }\end{array}$ & $\begin{array}{l}\text { Yes (risk } \\
\text { reduction) }\end{array}$ & $\begin{array}{l}\text { Yes (risk } \\
\text { reduction and } \\
\text { risk transfer) }\end{array}$ & $\begin{array}{l}\text { No (knowledge } \\
\text { dissemination) }\end{array}$ & $\begin{array}{l}\text { Yes (risk } \\
\text { reduction and } \\
\text { risk transfer) }\end{array}$ & $\begin{array}{l}\text { No (local-level } \\
\text { technical } \\
\text { assistance) }\end{array}$ \\
\hline $\begin{array}{l}\text { Type of } \\
\text { organisation }\end{array}$ & $\begin{array}{l}\text { Heterogeneous } \\
\text { (non- } \\
\text { governmental } \\
\text { organisations } \\
\text { and businesses) }\end{array}$ & $\begin{array}{l}\text { Homogeneous } \\
\text { (non- } \\
\text { governmental } \\
\text { organisations) }\end{array}$ & $\begin{array}{l}\text { Heterogeneous } \\
\text { (UN agency and } \\
\text { non- } \\
\text { governmental } \\
\text { organisations) }\end{array}$ & $\begin{array}{l}\text { Homogeneous } \\
\text { (sub-national } \\
\text { governments) }\end{array}$ & $\begin{array}{l}\text { Heterogeneous } \\
\text { (UN agency and } \\
\text { non- } \\
\text { governmental } \\
\text { organisations) }\end{array}$ & $\begin{array}{l}\text { Homogeneous } \\
\text { (non- } \\
\text { governmental } \\
\text { organisations) }\end{array}$ \\
\hline $\begin{array}{l}\text { Relative } \\
\text { importance of } \\
\text { the action vis-à- } \\
\text { vis other } \\
\text { activities }\end{array}$ & $\begin{array}{l}\text { Modest part of } \\
\text { the portfolio for } \\
\text { all partners }\end{array}$ & $\begin{array}{l}\text { Large part of the } \\
\text { portfolio for at } \\
\text { least one partner }\end{array}$ & $\begin{array}{l}\text { Large part of the } \\
\text { portfolio for at } \\
\text { least one partner }\end{array}$ & $\begin{array}{l}\text { Modest part of } \\
\text { the portfolio } \\
\text { (except for two } \\
\text { African } \\
\text { members) }\end{array}$ & $\begin{array}{l}\text { Large part of the } \\
\text { portfolio for at } \\
\text { least one partner }\end{array}$ & $\begin{array}{l}\text { Modest part of } \\
\text { the portfolio for } \\
\text { all partners }\end{array}$ \\
\hline $\begin{array}{l}\text { Delivery } \\
\text { mechanisms }\end{array}$ & $\begin{array}{l}\text { No mentioning } \\
\text { of "quality } \\
\text { control" }\end{array}$ & $\begin{array}{l}\text { No mentioning } \\
\text { of "quality } \\
\text { control" }\end{array}$ & $\begin{array}{l}\text { "Quality control" } \\
\text { is among the } \\
\text { main activities }\end{array}$ & $\begin{array}{l}\text { No mentioning } \\
\text { of "quality } \\
\text { control" }\end{array}$ & $\begin{array}{l}\text { "Quality control" } \\
\text { is among the } \\
\text { main activities }\end{array}$ & $\begin{array}{l}\text { No mentioning } \\
\text { of "quality } \\
\text { control" }\end{array}$ \\
\hline
\end{tabular}




\subsection{Interviewee responses}

Individually for each of the non-state actor actions studied, the following paragraphs present summaries of the feedback gathered through our interviews. Repetitions in the feedback reflect the similar objectives and delivery methods of the non-state actor actions studied.

\subsubsection{Business Alliance for Water and Climate}

Business Alliance for Water and Climate fills two kind of gaps. First, it generates and channels otherwise unavailable knowledge about climate change-induced water stresses that affect businesses. Second, it guides private companies in their interactions with international negotiations about climate-change adaptation. These functions fall at the interface between public policy and business strategy, and thus their fulfilment is of interest to both public- and private-sector actors.

At the international level, Business Alliance for Water and Climate responds to both peer and political pressure on developed country-multinational companies. Peer pressure has marketing and efficiency implications, both of which have some impact on profit-making and thus attract seniormanagement attention. Political pressure stems, in this case, from the willingness of the French government, as host to the 2015 conference of the parties to the UNFCCC, to display non-state actor action in the area of climate change. ${ }^{\text {xiv }}$ Both types of pressure are important drivers of Business Alliance for Water and Climate.

At the operational level, Business Alliance for Water and Climate relies on three assets. First, the credibility of the core partners, which strengthens their convening power. Second, the capabilities and competences of the core partners, which allow them to drive the action from the technical and strategic points of view. Third, the availability of the resources required to coordinate the work of the companies that have joined the action.

\subsubsection{Crisis Anticipation Window}

Crisis Anticipation Window mobilises funding to prevent disasters, and channels it to a network of non-governmental organisations that are active in disaster-prone regions. Much like Forecast-based Financing (see below), the objectives of Crisis Anticipation Window are aligned with the policies of aid-donor countries and the needs of aid-receiving countries. This alignment is seen as a fundamental pre-condition for success. At present, none of the state actors that could deliver the kind of disaster risk-management assistance provided by Crisis Anticipation Window do so. This delivery gap is a second pre-condition for the success of the non-state actor action. Not least, this gap gives the non-state actor action a "license-to-operate" vis-à-vis donors and, especially, beneficiaries.

To fill the delivery gap referred to above, Crisis Anticipation Window had to create a specialised delivery model, based on a network of non-governmental organisations that are well established in disaster-prone regions. The innovative nature of this delivery model, coupled with a selection of core partners that house (i) the required technical and project-management skills, and (ii) the coordination capabilities needed to act on extremely tight schedules, are further elements that account for the success of the non-state actor action.

To mobilise private sector funding, Crisis Anticipation Window capitalised on both its "brand" and the extent to which its delivery mechanisms are effective. Brands are a function of the values associated with them, the extent to which the population shares those values, and the level of visibility that a potential private-sector funder may achieve by associating its name to the brand. In practice, the first two factors become necessary-but-not-sufficient conditions, with visibility playing the determinant role. ${ }^{\mathrm{xv}}$ Effectiveness, which is a function of the technical and organisational skills 
accessible to the core partners, attracts two types of potential private-sector funders. First, funders that may be able to benefit directly from the skills of the partners in the non-state actor action, because these funders are active in a related field. Second, funders that are active in a completely different field, and for whom (very high) effectiveness is a pre-condition for making charitable contributions. The private-sector funders of Crisis Anticipation Window fall under the second category.

\subsubsection{Forecast-based Financing}

For aid-donor countries, preventing disaster in least-developed countries, the goal of Forecast-based Financing, is a strong political choice (both in its own right and from the point of view of the more efficient use of resources that it represents, compared to post-disaster relief). For aid-receiving countries, disaster-prevention efforts by non-state actors are among the few options that the poorest communities in these countries have to protect their livelihoods. ${ }^{\text {xvi }}$ Therefore, Forecastbased Financing is aligned with both donor policies and beneficiary country needs, which strengthens greatly its ability to deliver successfully.

With regard to implementation, Forecast-based Financing relies on two assets. First, a tight distribution of labour among highly specialised and well-coordinated core partners, which makes it possible for the non-state actor action to provide immediate responses when disasters are about to strike. Second, an innovative methodology, focused on risk-management, which has proven successful and, as a result, has attracted the interest of state actors. Indeed, a number of state actors have adopted the methodology. To catalyse this change, Forecast-based Financing had to (i) establish a close dialogue with state actors, ${ }^{\text {xvii }}$ and (ii) devote resources to transferring skills. In turn, and as a pre-condition to adopting the methodology, state actors had to strengthen their institutional capacities and regulatory frameworks.

Forecast-based Financing was successful at mobilising private sector funding. Two reasons account for this success. First, the perceived public-relations benefits of being associated with the Forecastbased Financing "brand". Second, the belief on the part of the private-sector funders that the work conducted by Forecast-based Financing was of good quality and thus represented a good use of charitable funds. Section 3.2.2 above gives additional details on the impact of "brands" and "effective delivery" in the context of mobilising private-sector funding.

\subsubsection{RegionsAdapt}

The decision to join RegionsAdapt, which is left to sub-national governments, is contingent on three interrelated factors. First, the availability of staff who have the time and expertise required to engage in this non-state actor action, which focuses on knowledge-sharing. Second, the benefits (in terms of both learning and visibility) that the sub-national government expects to obtain from joining. Third, a high level of citizen awareness about the near-term impacts of climate change. RegionsAdapt is most successful in sub-national jurisdictions where all three pre-conditions are met.

From the point of view of its design, RegionsAdapt capitalises on its ability to provide a public good that the relevant national governments provide only partly or not at all, namely documenting and disseminating knowledge about adaptation to climate change. It does so through a learning mechanism (based on the exchange of information among the various beneficiaries of the action) and a networking element (through the coordination role provided by the core partners in the action).

From the point of view of its implementation, RegionsAdapt relies mostly on the coordination and agenda-setting capabilities of the core partners. Although these partners are knowledgeable on 
climate change adaptation, the specialised expertise on which the action trades need not reside with them: it mostly resides with the sub-national governments that choose to join the action, precisely to share their expertise with other sub-national governments, and learn from them about adaptation-related issues. As a result, core-partner ability to coordinate and engage members (rather than deep technical expertise) are key determinants of success for RegionsAdapt.

\subsubsection{Rural Resilience Initiative}

Rural Resilience Initiative provides a range of risk-reduction and risk-transfer opportunities to poor communities in developing countries, with a focus on farmers. Most of the determinants of success mentioned by the other non-state actor actions studied apply to Rural Resilience Initiative. Specifically, Rural Resilience Initiative is consistent with aid-donor policies and the needs of aidrecipient countries, and it benefits from highly skilled and well-coordinate core partners.

Nonetheless, the key to its success lies on the quality and scope of the services it delivers, which go beyond basic risk-management approaches and have broken new ground in the field (Spiegel and Satterthwaite, 2013). The level of excellence of its operations is also the main reason for the success of Rural Resilience Initiatives at mobilising private-sector funding and catalysing related state actor action. ${ }^{\text {xviii }}$ For details on the services of Rural Resilience Initiative, the reader is referred to the wealth of online material, notably the annual reports prepared by the core partners in the initiative.

\subsubsection{Urban Community Resilience Assessment}

Urban Community Resilience Assessment relies on development aid to support adaptation to climate change by informal communities in large urban areas. Therefore, two key determinants of success are the extent to which this type of support is consistent with the priorities of developmentaid agencies, and the relative importance of this work vis-à-vis other climate change-adaptation activities in the portfolio of development-aid agencies.

For the local authorities benefitting from Urban Community Resilience Assessment, the support that they receive is of immediate practical application. However, "values", even more than "outputs", are the key drivers of engagement by these local authorities. Indeed, given the one-off nature of Urban Community Resilience Assessment, and the limited selection of informal communities that it can reach, given its limited budget, the appeal of the action lies in the principles it stands for. Therefore, to some degree, the likelihood of success of Urban Community Resilience Assessment is influenced by the extent to which its principles are cherished by the local authorities concerned.

When it comes to on-the-ground delivery, Urban Community Resilience Assessment relies on the capabilities and competences of the core partners, notably their technical expertise and their ability to administer development-aid funds. Not least, the non-state actor action relies for its success on the gap it fills: the public good it provides, which would not be provided by public authorities.

\subsection{A taxonomy to assess the likelihood of successful delivery}

The responses from our interviewees touch upon three distinct sets of issues. A first set of issues relates to conditions that tend to change slowly and only as a response to forces that are beyond the sphere of influence of the non-state actor action. Examples of these conditions are the extent to which state actors provide climate change-adaptation or disaster risk-reduction services to vulnerable communities, or the extent to which development aid agencies are willing to support non-state actors that provide these services.

A second set of issues relates to the type of policy and regulatory environment within which a nonstate actor action operates, the extent to which the core partners in the action have the skills required to operate in that environment, and the interactions with other actors that are active in the 
same environment. One example of these issues is the partnerships that the non-state actor actions surveyed establish with actors that have a strong on-the-ground presence. Crisis Anticipation Window and Urban Community Resilience Assessment are cases in point. A second example of these issues is the degree to which state actors are in a position to change regulatory and institutional frameworks, in spite of institutional inertias, to adopt relevant approaches by non-state actors. Forecast-based Financing is possibly the best example of this.

A third set of issues relates to the workings of the non-state actor action itself, the main elements of which are the choice of delivery method and the interactions between core partners to implement the delivery method chosen. Rural Resilience Initiative provides a paradigmatic example of the importance of the delivery method. With their focus on servicing a relatively large membership, RegionsAdapt and Business Alliance for Water and Climate are examples of the importance that the interaction among partners has for the success of the non-state actor action.

The three sets of issues described above can be generalised into the following three dimensions, which constitute our taxonomy for assessing the likelihood that delivery by non-state actor actions may be successful:

- The first dimension, which we label "societal conditions", refers to issues that take years to change and have a clear, albeit indirect influence on the work of non-state actor actions. Examples of these issues include near-term vulnerability to the impacts of climate change, societal support (in donor countries) for development aid, or the extent to which civil society is involved in policy-making and public-private partnerships are used to implement policy, among other issues.

- The second dimension, which we label "domain conditions", refers to three types of issues, all of which have a direct influence on the work of the non-state actor action. First, the capabilities and competences of the partners in the action, and the extent to which they complement one another. Second, the policy and regulatory environment within which the non-state actor action operates. Third, the agendas of the related stakeholders that operate within the same economic and regulatory environment.

- The third dimension, which we label "action conditions", refers to the choice of delivery method made by the non-state actor action, the specific design of the method, and the way in which the different partners in the action interact with one another to apply that method.

The taxonomy introduced above seeks to identify the full range of issues that have an impact on the likelihood that non-state actors deliver on their commitments. Stated differently, although the relative importance of the issues may vary, depending on the non-state actor action concerned, in the context of an ex-ante assessment of non-state actor action, all the issues included in the taxonomy deserve consideration.

The taxonomy seeks to raise awareness among future non-state actor actions about the need to take a comprehensive look at all the issues that may have an impact on delivery, and to do so early on. Ultimately, the goal of the taxonomy is to help increase the effectiveness of future non-state actor actions. 


\section{Discussion}

This section is structured around two elements. First, we discuss some of the limitations of our taxonomy, and put forward a number of considerations regarding its use. Second, we compare the taxonomy with related criteria documented in the literature on non-state actor action.

\subsection{Limitations of the taxonomy and considerations regarding its use}

Our taxonomy has not been tested empirically and thus remains exploratory. As such, it is subject to a number of limitations. These limitations are outlined in the following paragraphs, along with various considerations regarding the use of the taxonomy.

Our data suggest that interactions across the three dimensions in the taxonomy exist, but should be analysed on a case-by-case basis. Stated differently, the nature and extent of the interactions depends on the context and cannot be generalised. Nonetheless, for the purpose of developing a taxonomy that identifies all relevant issues, specifying those interactions is not necessary.

Further, our data suggest that the taxonomy applies equally to non-state actor actions focused on adaptation or disaster-risk reduction. This notwithstanding, the latter appear to have larger net impacts, as noted in Section 3.2. This observation would suggest that ex-ante assessments of the sort that the taxonomy facilitates may be especially useful for non-state actor actions focused on adaptation.

The taxonomy is influenced by our definition. Indeed, as noted by an anonymous reviewer, the type of definition chosen (Supplementary Information 1) directs our analysis toward transnational climate governance initiatives. As a result, our findings will reflect this type of initiatives better, and may not be applicable to other types of non-state actor actions.

Of particular importance is the question of whether or not our taxonomy is comprehensive, in the sense of encompassing all issues that are relevant to delivery by non-state actor actions.

Supplementary Information 4 sketches an attempt at determining the extent to which the taxonomy is comprehensive.

The taxonomy does not distinguish between direct and indirect impacts, because the two kinds of impacts are inextricably linked to one another. Therefore, it is not possible to single out the issues that "predominantly" affect direct (or indirect) impacts. ${ }^{\text {xix }}$

Similarly, it is not possible to discern the relationships between the different dimensions that make up the taxonomy. This would require that a specific analysis is undertaken at the level of individual non-state actor actions (as of today, no non-state actor actions has done so), coupled with an effort to generalise the findings of these individual analyses.

Finally, we can only hypothesise about the extent to which the taxonomy would be applicable to non-state actor actions focused on climate-change mitigation. Based on our experience, we can conjecture that it would, although with one important caveat: the international dimension would be much more prominent at the level of the domain conditions, notably in the form of competitiveness concerns among first movers.

\subsection{Comparing the three dimensions in our taxonomy with the criteria in the literature}

In Section 1, we refer to three sets of criteria that can be used to assess the likelihood that a nonstate actor actions delivers on its objectives. In the following paragraphs, and individually for each of these three sets of criteria, we analyse the extent to which the various criteria overlap with the 
range of issues covered by our taxonomy. This comparison reveals that our taxonomy is fully consistent with the criteria in the literature. The main difference is that our taxonomy covers a broader set of issues (Table 3).

\subsection{1 "Effectiveness, legitimacy and institutional-fit" criteria}

Widerberg and Pattberg (2015) put forward three criteria, each with two sub-criteria attached. We analyse each sub-criterion individually.

Sub-criterion 1: does the mix of partners in the non-state actor action "reflect the problem it addresses"? Since the focus is on the mix of partners, the notion of "reflecting the problem" is akin to the notion of capabilities and competences, under our "domain conditions".

Sub-criterion 2: is the required technical and financial capacity available? Here, too, there is overlap with the capabilities and competences element under our "domain conditions".

Sub-criterion 3: is the target group represented, and is decision-making power equally distributed among partners? The first element in this sub-criterion relates to the need to consider other stakeholders' agendas (under our "domain conditions"). The second element relates to the concept of interactions between partners (under our "action conditions"). ${ }^{\mathrm{xx}}$

Sub-criterion 4: do the partners and the broader public have access to information? At the level of principles, access to information relates to our "societal conditions", whereas it relates to capabilities and competences (under our "domain conditions") when it comes to the skills and resources needed to access and distribute information.

Sub-criterion 5: does the non-state actor action have a clear institutional niche? Although related to our "societal conditions", the concept of institutional niche fits better with the need to consider other stakeholders' agendas (under our "domain conditions"), because the partners in the action have some control (at the design stage) over the extent to which the output of the non-state actor action will complement the outputs by other stakeholders.

Sub-criterion 6: is the non-state actor action responding to a governance gap? Although related to the choice and design of the delivery method (under our "action conditions"), the concept of governance gap fits better with our "societal conditions".

\subsection{2 "Design" criteria}

Michaelowa and Michaelowa (2017) put forward three "design criteria": the extent to which (i) explicit targets have been set; (ii) incentives are available; and (iii) monitoring, reporting and verification procedures have been adopted. They screen individual non-state actor actions against each of these criteria.

The incorporation of explicit targets relates to the delivery method, which falls under our "action conditions". The same is true with regard to the adoption of monitoring, reporting and verification procedures. However, the notion of "adoption" does not necessarily include design and implementation considerations. Stated differently, procedures may have been adopted that are not workable, because the partners in the action lack the required technical and coordination capabilities, or the resources available are incommensurate with the task at hand.

The availability of incentives is linked to our "action conditions", in the sense that incentives can (and should) be introduced by design in the delivery method. In addition, the availability of incentives is linked to our "domain conditions", because the policy and regulatory environments shape the impact that any incentives will have. 


\subsection{3 "Function-output fit" criteria}

Chan and Amling (2019) map functions against outputs. ${ }^{x \times i}$ They assign as many functions as relevant to a non-state actor action, and analyse the extent to which the outputs of that action are likely to fulfil all the functions concerned.

The outputs considered by Chan and Amling relate mainly to one type of "domain condition", namely the capabilities and competences of the partners in the non-state actor action. The output labelled "provision of professional advice" represents the most obvious example.

To a lesser extent, the outputs considered by Chan and Amling also relate to one aspect of "action conditions", namely the choice of delivery method. However, their assessment stops with the categorisation of the method (see footnote 20), thus falling short of assessing the likelihood that the delivery method may be successful. 
Table 3: Extent to which the criteria in the literature consider the issues included in our taxonomy

\begin{tabular}{|c|c|c|c|}
\hline & $\begin{array}{l}\text { Widerberg and } \\
\text { Pattberg (2015) }\end{array}$ & $\begin{array}{l}\text { Michaelowa and } \\
\text { Michaelowa (2017) }\end{array}$ & Chan and Amling (2019) \\
\hline Societal conditions & Considered (partly) & & \\
\hline \multicolumn{4}{|l|}{ Domain conditions } \\
\hline - capabilities and competences & Considered (partly) & & Considered \\
\hline - economic and regulatory environment & & Considered (indirectly) & \\
\hline - $\quad$ agendas of other stakeholders & Considered & & \\
\hline \multicolumn{4}{|l|}{ Action conditions } \\
\hline - choice and design of the delivery method & & Considered & Considered (partly) \\
\hline - $\quad$ interactions between partners & Considered (narrowly) & & \\
\hline
\end{tabular}

Note: explanations are provided in sections 4.2.1 to 4.2.3. 


\section{Conclusions}

We find that successful delivery by non-state actor actions depends on the alignment of several parameters. Some of these parameters are under the direct control of non-state actors. The extent to which the core partners in the action have access to the resources and skills required to implement the action is a prime example of this type of parameters. However, most parameters escape the control of the non-state actor action. Key among these are the policy and regulatory environment within which the non-state actor action operates, or the extent to which a community perceives non-state actors as acceptable alternatives to state-actor action.

Our taxonomy helps identify the determinants of successful delivery by non-state actor actions both those that are under the direct control of non-state actors, and those that escape their control. Using the taxonomy to assess ex-ante the likelihood that a non-state actor action may deliver on its objectives would make it possible to improve the design of non-state actor actions. We argue that such ex-ante assessments could underpin a "good practice" standard, administered by an independent party, which can be used to raise the bar for non-state actor action. The United Nations Environment Programme could play such a role (Bakhtiari, 2018). The United Nations Office for Partnerships may be a further relevant option.

Our findings point toward four potential future research areas related to the design of non-state actor actions. First, the rationale of private sector funders. As noted above, visibility and the extent to which funders may benefit from the technical approach used by non-state actors seems to determine whether and which type of businesses fund non-state actors. Second, the interplay between the governance mechanism chosen and the gap that a non-state actor action feels. Our analysis suggests that strong public sector involvement (through hierarchical or orchestrated governance arrangements) goes hand in hand with big "action gaps" and large impact, but we cannot tell how the various factors influence one another. Third, the relative importance of the governance form chosen. The selection of non-state actor actions that we surveyed suggests that the actions started through hierarchical or orchestrated governance forms have been more conscious about quality assurance procedures. Fourth, the barriers to indirect impacts by non-state actors, notably catalysing related but independent action by state actors. Without attempting to prove it, we hypothesise that the efforts by state actors to adopt successful non-state actor approaches face two constraints: limited institutional capacities within government, and institutional inertias.

\section{References}

Andonova, L.B., Betsill, M.M. and Bulkeley, H. (2009). Transnational climate governance. Global environmental politics, 9(2), 52-73.

Andonova, L.B., Hale, T.N. and Roger, C.B. (2017). National policy and transnational governance of climate change: Substitutes or complements? International Studies Quarterly, 61(2), 253-268.

Bakhtiari, F. (2017, July 7). Non-state actors are here to stay, but delivery mechanisms need improvement [Blog post]. Retrieved from https://climatestrategies.wordpress.com/2017/07/07/non-state-actors-are-here-to-stay-butdelivery-mechanisms-need-improvement/ 
Bakhtiari, F. (2018). International cooperative initiatives and the United Nations framework convention on climate change. Climate Policy, 18(5), 655-663.

Bulkeley, H. and Schroeder, H. (2012). Beyond state/non-state divides: Global cities and the governing of climate change. European Journal of International Relations, 18(4), 743-766.

Bulkeley, H., Betsill, M., Compagnon, D., Hale, T., Hoffmann, M., Newell, P. and Paterson, M. (2018). Transnational governance. In Jordan, A., Huitema, D., van Asselt, H. and Forster, J. (eds.) Governing climate change: policentricity in action? (pp. 63-80). Cambridge. Cambridge University Press.

Chan, S., Falkner, R., van Asselt, H. and Goldberg, M. (2015). Strengthening non-state climate action: a progress assessment of commitments launched at the 2014 UN Climate Summit. London School of Economics and Political Science, and German Development Institute. London and Berlin.

Chan, S., Falkner, R., Goldberg, M. and van Asselt, H. (2018). Effective and geographically balanced? An output-based assessment of non-state climate actions. Climate Policy, 18(1), 24-35.

Chan, S. and Amling, W. (2019). Does orchestration in the Global Climate Action Agenda effectively prioritize and mobilize transnational climate adaptation action? International Environmental Agreements: Politics, Law and Economics, 1-18.

CDP (2019). Major risk or rosy opportunity: are companies ready for climate change? CDP, London.

CIP (2019, n.d.). Climate Initiatives Platform. Retrieved from http://climateinitiativesplatform.org/

Dzebo, A. and Stripple, J. (2015). Transnational adaptation governance: an emerging fourth era of adaptation. Global Environmental Change, 35, 423-435.

Dzebo, A. (2019). Effective governance of transnational adaptation initiatives. International Environmental Agreements: Politics, Law and Economics, 19(4-5), 447-466.

Fenhann, J.V., Konrad, S., Wretlind, P.H., Høgsbro, S.K. and Drost, P. (2018). The Climate Initiatives Platform: towards greater transparency in international cooperative climate initiatives (TemaNord 2018:552). Nordic Council of Ministers. Copenhagen.

GRP (2019). The Global Resilience Partnership. Retrieved from https://www.globalresiliencepartnership.org/

Hermwille, L. (2018). Making initiatives resonate: how can non-state initiatives advance national contributions under the UNFCCC? International Environmental Agreements: Politics, Law and Economics, 18(3), 447-466.

Hsu, A., Widerberg, O., Weinfurter, A., Chan, S., Roelfsema, M., Lütkehermöller, K. and Bakhtiari, F. (2018). Bridging the emissions gap: the role of non-state and subnational actors. In Olhoff, A. and Christensen, J.M. (eds.) The emissions gap report 2018: a UNEP synthesis report (pp. 29-42). United Nations Environment Programme. Nairobi.

Höhne, N. and Drost, P. (2015). Bridging the gap: the role of non-state action. In Olhoff, A. and Christensen, J. (Eds.) The emissions gap report 2016: a UNEP synthesis report. (pp. 23-30). United Nations Environment Programme. Nairobi.

Michaelowa, K. and Michaelowa, A. (2017). Transnational climate governance initiatives: designed for effective climate change mitigation? International Interactions, 43(1), 129-155. 
Roger, C. and Dauvergne, P. (2016): The rise of transnational governance as a field of study. International Studies Review, 18(3), 415-437.

Spiegel, A, and Satterthwaite, D. (2013). The R4 Rural Resilience Initiative: protecting livelihoods in a changing climate. In Orie, M. and Stahel, W.R. (Eds.) Insurers' contributions to disaster reduction: a series of case studies. (pp. 65-70). The Geneva Association. Geneva.

UNFCCC (2015). Adoption of the Paris Agreement (FCCC/CP/2015/L.9/Rev.1). United Nations Framework Convention on Climate Change. Bonn.

UNFCCC (2019). Chile Madrid time for action (Decision 1/CP.25). United Nations Framework Convention on Climate Change. Bonn.

van der Ven, H., Bernstein, S. and Hoffmann, M. (2017). Valuing the contributions of nonstate and subnational actors to climate governance. Global Environmental Politics, 17(1), 1-20.

Widerberg, O. and Pattberg, P. (2015). International cooperative initiatives in global climate governance: raising the ambition level or delegitimizing the UNFCCC? Global Policy, 6(1), 45-56.

Widerberg, O. and Stripple, J. (2016). The expanding field of cooperative initiatives for decarbonization: a review of five databases. Wiley Interdisciplinary Reviews: Climate Change, 7(4), 486-500. 


\title{
Endnotes
}

\begin{abstract}
'Transnational governance can be defined by opposition to what might be called 'intergovernmental governance', which refers to the set of rules that govern the collective efforts of at least two state actors pursuing a shared, public goal (Roger and Dauvergne, 2016). Thus, 'intergovernmental governance' would be restricted to national-level governments, and would exclude explicitly non-state actors.
\end{abstract}

ii In decision 1/CP.21, through which the Paris Agreement is implemented, paragraph 117 «welcomes the efforts of non-Party stakeholders to scale up their climate actions», whilst paragraph 118 "encourages Parties to work closely with non-Party stakeholders to catalyse efforts to strengthen mitigation [...] action» (UNFCCC, 2015). Paragraph 134 in the same decision «invites [...] non-Party stakeholders [...] to scale up their efforts and support actions to reduce emissions» (ibid).

iii Most non-state actor actions focus on climate change mitigation mainly because, compared to adaptation to climate change and to disaster-risk reduction, mitigation action has a much longer history.

${ }^{\text {iv }}$ Although some of these studies explore both direct and indirect impacts, most focus on direct impacts.

${ }^{v}$ It is worth noting that indirect impacts can be both positive and negative (van der Ven et al., 2017).

vi Studies of non-state actor actions that focus exclusively on adaptation to climate change are scarce, partly because practice is still limited. Dzebo and Strippe (2015) authored the first such studies, to which a second one was added recently (Dzebo, 2019). Most other studies of adaptation-focused non-state actor actions also cover their mitigation-focused counterparts. A review by Michaelowa and Michaelowa (2017) provides an example of this.

vii Human development-oriented non-state actor actions potentially overlap with adaptation-focused actions. The study excludes the former, and includes only those that bill themselves as focused on adaptation (or disaster-risk reduction).

viii To identify this initial set of actions, we relied on the Climate Initiatives Platform (CIP, 2019), which makes it possible to select initiatives based on focus area.

ix Specifically, the interviews allowed us to judge whether the core partners in each of the actions studied had an empirically-based understanding of the determinants of delivery, acquired through the experience gained implementing the action.

${ }^{x}$ It is worth noting that there is no link between the approach to selecting non-state actor actions and the approach to designing the survey form. Stated differently, the number of actions selected, and the process to select them, is independent from the information collected through the survey.

${ }^{x i}$ Further to an initial contact by e-mail, survey respondents were briefed on the phone about the scope and goal of the survey. They submitted their responses by e-mail. A second phone conversation was used to ensure that the responses provided were fully aligned with the type of response sought. This helped increase, across respondents, the comparability of the responses received.

xii Five of the six non-state actor actions studied report on their activities (Table 2). Evidence of delivery by these non-state actor actions is included in these reports, which are scrutinised by third parties. As for the remaining action, we conducted additional interviews (with sub-national government agency staff involved in the action), to understand whether the action delivered on its objectives.

xiii That a non-state actor action delivers on its stated objectives says nothing about the level of ambition of those objectives, or about the efficiency with which delivery occurred. 
${ }^{\text {xiv }}$ As stated by one of our interviewees.

${ }^{x v}$ In the context of the visibility sought by potential private sector funders, it is interesting to note that Forecast-based Financing and Rural Resilience Initiative, which have a narrow focus, have raised larger amounts of private sector funds, compared to Crisis Anticipation Window, which has a broader focus. As indicated by our interviewees, the broader the focus, the more reduced the visibility and thus the more difficult it becomes to mobilise private-sector funding.

xvi This non-state actor action targets least-developed countries, where the poorest can seldom expect assistance from domestic governmental agencies.

xvii The closer the dialogue, the more effective the non-state actor action is likely to be and, in the mid- to longterm, the higher the chances that state actors choose to adopt a successful non-state actor approach.

xviii Several core partners in Forecast based Financing and one core partner in Crisis Anticipation Window assessed Rural Resilience Initiative as performing at the highest level in the areas of risk reduction and risk transfer.

xix For example, an underdeveloped regulatory framework may spur disaster-risk reduction activities by nonstate actor actions. Yet, the same sub-optimal regulatory framework can also hinder these activities when, for example, credit-market regulations are inefficient or absent. Not least, it is the same underdeveloped regulatory framework that will hamper the uptake of those activities by state actors.

${ }^{x x}$ It is worth noting that "equal distribution of power" unduly rules out other legitimate types of interactions.

xxi Examples of functions include "knowledge production", "norm and standard setting" or "policy planning", among others. Examples of outputs include "publications", "funding" or "events", among others.

Chan et al., (2015) provide a listing of functions and outputs (see Table 1 and Table 2, respectively, in Annex 1). 